\title{
Bacterial problems associated with scallop Pecten maximus larval culture
}

\author{
J. L. Nicolas ${ }^{1, *}$, S. Corre ${ }^{2}$, G. Gauthier ${ }^{3}$, R. Robert $^{1}{ }$, D. Ansquer ${ }^{1}$ \\ ${ }^{1}$ Laboratoire Mollusque, Aquaculture, IFREMER, Centre de Brest, BP 70, F-29280 Plouzané, France \\ ${ }^{2}$ Micromer, rue Charles-Cadiou, ZI du Vernis, F-29200 Brest, France \\ ${ }^{3}$ CNRS \& Université Paris 6, Station Zoologique, F-06230 Villefranche sur Mer, France
}

\begin{abstract}
Scallop Pecten maximus larvae have been cultured at the Argenton and Tinduff (Brittany, France) hatcheries with antibiotic treatment (chloramphenicol at $8 \mathrm{ppm}$ ) for $15 \mathrm{yr}$. Without treatment, outbreak of disease has normally occurred between Day 12 and Day 19 or sometimes earlier. A bacteriological study of larvae reared with and without antibiotic was performed over a 4 yr period. Among the collected strains, 2 clusters $(C$ and $F$ ) of vibrios were present at high densities only in larvae cultured without treatment. One cluster (C) was routinely isolated over the 4 yr of study, while the other (F) was collected only in the third year. Their virulence with respect to scallop larvae and their lack of infectivity with respect to oyster larvae were demonstrated in an exposure experiment. The vibrio $\mathrm{F}$ strain tended to lose its virulence after 5 subcultures, whereas the vibrio $C$ strain retained the ability to kill scallop larvae in experimental infections. Three other vibrios isolated in moribund oyster larvae caused mortality in oyster larvae but not in scallop larvae. Different methods were used to determine the taxonomic position of these virulent bacteria. The phenotypic traits of bacterial isolates were determined with the Biolog GN microplate, the API 20 E system and the reference method. Patterns of cytoplasmic proteins were identified by electrophoresis in SDS-PAGE. These different methods consistently confirmed the existence of 2 vibrio species pathogenic to scallop larvae. Affiliation of cluster $F$ with Vibrio splendidus was assessed by Biolog tests and by analysis of $16 \mathrm{~S}$ rRNA sequences. One pathogenic bacteria of oyster larvae was also very close to this second cluster, whereas the 2 others from moribund oyster larvae and cluster $C$ may constitute 2 different species.
\end{abstract}

KEY WORDS: Larvae Bivalve - Vibrio Scallop

\section{INTRODUCTION}

Generally, culture of bivalve larvae does not require antibiotic treatment except in instances where bacterial infections occur. Bacterial diseases are periodically observed in bivalve larval culture and can severely limit production (DiSalvo et al. 1978, Brown \& Russo 1979, Elston \& Leibovitz 1980, Brown 1981, Brown \& Tettlebach 1988, Nicolas et al. 1992) but they may not impede post-larvae production if precautions are taken. Elston (1984), in a general review on infectious diseases of larval bivalves, gave the principles of disease prevention. They include disinfection of materials

\footnotetext{
•E-mail: jlnicola@ifremer.fr
}

and tanks with chlorine, use of separate sets of equipment, strict separation of different culture batches, cleaning and regular stops in operations. Diagnosis of diseases and determination of the sources of contamination provide a basis for disease management and for taking appropriate measures, such as UV treatment of inflowing sea water, to prevent infection. Antibiotic treatment as a preventive measure is not recommended (Martin \& Vicente 1975) because it is expensive and can result in the selection of antibiotic-resistant bacteria. Furthermore, some antibiotics, especially chloramphenicol, could affect larval development by inhibiting mitochondrial protein synthesis (Standiford 1985). Nevertheless, in 2 hatcheries (Argenton and Tinduff near Brest, Brittany, France) chloramphenicol has been added to scallop larval culture as a preven- 
tive measure for more than $10 \mathrm{yr}$ without the appearance of resistant pathogenic bacteria or abnormalities in larval or adult scallop development. In the absence of treatment, there was either a gradual or a sudden increase in larval mortality

A bacteriological study over 4 years (1990 to 1993) was conducted at the Argenton hatchery in order to examine the causes of larval mortality that occurs without treatment. Scallop Pecten maximus and oyster Crassostrea gigas larvae were exposed to representative isolates collected during bacterial diseases in scallop and oyster larvae. Several different methods were performed for bacterial identification.

\section{MATERIALS AND METHODS}

Culture of scallop larvae. Brood stock originating from the bay of Brest was conditioned in the hatchery, according to the method of Devauchelle \& Mingant (1991). Spawning was induced by thermal shock, and eggs were fertilised by the method described by Gruffydd \& Beaumont (1970). Two days after fertilisation D-larvae were distributed in $400 \mathrm{l}$ tanks at 7 larvae $\mathrm{ml}^{-1}$. Inflowing sea water was filtered at $1 \mu \mathrm{m}$, maintained at $18^{\circ} \mathrm{C}$ and renewed every 2 to $3 \mathrm{~d}$. Larvae reached the umbo stage at Days 8 to 10 . They became pediveligers at Days 15 to 17 . The eyed stage was achieved at Days 17 to 19. Metamorphosis occurred from Days 21 to 23. In the first 3 experiments $(1$ experiment a year), 1 tank was left without antibiotic treatment while the control tank received chloramphenicol at $8 \mathrm{ppm}$. Because these experiments were performed simultaneously with others, only 1 tank was available for the larval culture without treatment. However, all previous assays of non-treated larval culture in several tanks had always shown a similar development of mortality in all batches. For the fourth experiment, 3 batches of 2 tanks containing different concentrations of larvae (1, 2.5 and 5 larvae $\left.\mathrm{ml}^{-1}\right)$ were left without antibiotic. The control batch at 5 larvae $\mathrm{ml}^{-1}$ received the usual antibiotic dose.

Larvae were fed with an algal mixture of Pavlova Iutheri (Droop), Isochrysis affinis galbana (Parke) (Tiso), and Chaetoceros calcitrans (Takano). Microalgae were grown in batch culture, harvested during the exponential phase and distributed at a final concentration of 20 cells $\mu^{-1}$ for each species. At every renewal of sea water ( 3 times a week) the number of dead and abnormal larvae was determined on 3 samples of at least 100 larvae. The shell length was determined by measuring a sample of 50 larvae using a Nikon profile projector (microscope with a screen).

For the experimental exposure oyster Crassostrea gigas larvae were used. Brood stock originating from the bay of Brest was conditioned in the hatchery under conditions indicated above, except temperature (18 to $20^{\circ} \mathrm{C}$ instead of $15^{\circ} \mathrm{C}$ ). Spawing and culture of larvae were performed in the same conditions as for scallop. except temperature $\left(22\right.$ to $24^{\circ} \mathrm{C}$ instead of $18^{\circ} \mathrm{C}$ ).

Bacteriology. Samples $(100 \mathrm{ml})$ of larval culture sea water (SW) were collected after filtration of larval cultures on a plankton net of mesh size $80 \mu \mathrm{m}$. All larvae retained by the plankton net were rinsed with nonsterile sea water, resuspended and homogenised in $2 \mathrm{l}$ of SW. Another $2 \mathrm{ml}$ of culture sea water containing on average of 1000 larvae were later sampled. These larvae were rinsed by sterile SW (SSW) and resuspended in $3 \mathrm{ml} \mathrm{SSW}$. All dead and living larvae were counted in $1 \mathrm{ml}$ of this sample, which contained between 200 and 400 larvae as determined by using a Nikon profile projector. Larvae were considered dead when soft tissues were absent or partially degraded or when the larvae showed an absence of ciliary movements. The remaining larvae in the $2 \mathrm{ml}$ SSW were ground in a sterile homogenizer. Sea water and ground larvae were diluted by serial 10 fold dilutions in SSW, after which $0.1 \mathrm{ml}$ was plated on Zobell agar and TCBS (thiosulfate citrate bile salts sucrose) (Difco). Colonies on TCBS and on Zobell agar were respectively counted after $48 \mathrm{~h}$ and $8 \mathrm{~d}$ incubation.

Dominant colonies, about 10 per plate on both media, were isolated and purified. Their metabolism and growth preferences were determined on 96-well microtitrate plates using 31 characters including reduction of nitrates; acidification of glucose, sucrose, arabinose, mannose and sorbitol; growth in a single source of carbon, i.e. tyrosine, galactose, glucuronate, inositol, cellobiose, gluconate, glucose, mannose, alanine, sucrose, glycerol, mannitol, melibiose or succinate; production of indol from tryptophane; presence of $\beta$-galactosidase, gelatinase, amylase or tween-esterases (tween 80 and 20 ), growth in $0.2,3,6,8$ or $10 \%$ $\mathrm{NaCl}$. The microtitrate plates were incubated for $8 \mathrm{~d}$ at $20^{\circ} \mathrm{C}$ in closed boxes to avoid evaporation. Nine additional tests including glucose fermentation (Hugh and Leifson), oxidase, catalase, growth at 6 and $30^{\circ} \mathrm{C}$, pigmentation, mobility and Gram were performed with all strains. A taxonomic program permitted the construction of a dendrogram that grouped the isolates sharing these 40 characters

Further identification of potentially pathogenic bacteria. Additional metabolic properties were determined for the isolates A 365, A 060, A 053 and A 515, which represented both clusters of virulent bacteria, for the isolates V 110 and S 322 from moribund oyster larvae and for 2 reference bacteria, Vibrio splendidus (American Type Culture Collection, ATCC 33125) and Vibrio alginolyticus (ATCC 17749) 
Classical characters were determined with the commercial kit API 20E (BioMérieux) according to the method of MacDonell et al. (1982), which includes the following arginine dehydrolase, ornithine decarboxylase, lysine decarboxylase, indole and acetyl methyl carbinol production, acidification of inositol, rhamnose, sucrose, melibiose, mannitol, sorbitol, melibiose, amygdaline, arabinose, glucose, $\beta$-galactosidase, gelatinase, nitrate reduction and oxidase. Other metabolic preferences, i.e. use of single source of carbon, were determined according to the methods of Baumann \& Baumann (1981): L $\alpha$-alanine, L $\beta$-alanine L-arginine, casein, citrate, D-cellobiose, ethanol, D-gluconate, glucose, glycine, L-histine, L-leucine, D-mannitol, Lornithine, propionate, pyruvate, sucrose, D-sorbitol, Ltyrosine and isovalerate.

Growth at $4,30,35$ and $42^{\circ} \mathrm{C}$ in marine broth and in $0.2,3,6,8$ and $10 \% \mathrm{NaCl}$ with tryptone $\left(2 \mathrm{~g} \mathrm{l}^{-1}\right)$ were observed. Sensitivity to $0 / 129$ at 10 and $150 \mu \mathrm{g}$ per disc was tested on marine agar. In addition, the Biolog GN microplate permitted determination of 95 characters of nutrient utilisation.

Based on the 50 classical characters and the 95 tests determined on the Biolog GN microplate, 2 different numerical taxonomic determinations were performed.

In order to evaluate the cytoplasmic protein patterns, bacteria were cultured in marine broth, harvested by centrifugation, rinsed with sterile sea water and then broken by sonication $(15 \mathrm{kHz}, 1$ min $\times 3$ times $)$. Unbroken cells and membranes were separated by centrifugation ( $40000 \times g$ for $15 \mathrm{~min}$ at $4^{\circ} \mathrm{C}$ ) and discarded. The supernatant containing the cytoplasmic proteins was collected. The protein concentration was determined according to the Lowry method (Lowry et al. 1951). The samples containing about $1 \mathrm{mg}$ protein $\mathrm{ml}^{-1}$ were dissolved in SDS buffer, placed in boiled water for 5 min and loaded onto a polyacrylamide $(10 \%)$ gel. Current was left to run for $1 \frac{1}{2} \mathrm{~h}$. The protein bands were stained by Coomassie Brilliant blue. Bacterial identification was deduced from the protein patterns by the method of Jackman (1985). According to this method, every protein band is considered as a phenotypic character and the numerical taxonomy is applied as for other phenotypic characters.

GC (guanine-cytosine) content was determined by measuring the melting temperature according to the method of De Ley (1970). DNA was extracted, purified with Phenol-Chloroform-Isoamyl (PCI) alcohol and precipitated by cold ethanol. DNA of Clostridium perfringens, Micrococcus luteus and Escherichia coli (Sigma) were used as reference for calibration of GC content.

The small-subunit rDNA, which correspond to $16 \mathrm{~S}$ IRNA in DNA, were sequenced from polymerase chain reaction (PCR) products as described by Ruimy et al. (1994). These sequences were aligned by reference to a database of about 2000 eubacterial 16S IRNA sequences including more than 100 vibrios.

Phylogenetic analysis was performed using 3 different methods: neighbour-joining (NJ), maximum likelihood (ML) and maximum parsimony (MP).

Experimental exposure of larvae to isolated bacte ria. Seven-day-old scallop (Pecten maximus) larvae were placed at a concentration of 6 larvae $\mathrm{ml}^{-1}$ in 21 flasks filled with $0.2 \mu \mathrm{m}$ filtered sea water. Larvae were incubated at $18^{\circ} \mathrm{C}$ and fed with the algal mixture previously indicated. All scallop larvae were provided by the experimental hatchery in Argenton.

Eight-day-old oyster (Crassostrea gigas) larvae were maintained at 22 to $24^{\circ} \mathrm{C}$ in 2 I flasks containing 6 larvae $\mathrm{ml}^{-1}$.

Bacterial strains A 365, A 060, A 053, A 515 and a non-vibrio strain, $\mathrm{T} 416$, isolated in moribund scallop larvae were cultured for $24 \mathrm{~h}$ in marine broth, centrifuged, resuspended in sterile sea water and inoculated in sea water containing larvae in triplicate at a final concentration of $10^{4}$ cell $\mathrm{ml}^{-1}$. Three flasks of nonexposed larvae were kept as controls.

At every renewal of sea water, mortality and behaviour of larvae were checked. Bacteria in sea water and/or larvae were counted on Zobell agar and TCBS as previously indicated in the first experiments.

Additional experimental exposures were performed with the strains S 322, I 168 and V 110, isolated from moribund oyster (Crassostrea gigas and Ostrea edulis) larvae. The vibrio A 365 was used as a reference pathogen. These strains were tested on scallop larvae, as well as on oyster (C. gigas) larvae in 2 replicates under similar conditions except for the temperature of the larval culture (22 to $24^{\circ} \mathrm{C}$ for oyster larvae).

\section{RESULTS}

\section{Natural outbreak of larvae reared without antibiotic}

Over the 4 years of experiments, antibiotic-free larval cultures shared similar features. Larval mortalities systematically occurred between Day 14 and Day 21, while the control with chloramphenicol remained alive for the duration of experiments. Some variations were observed. Increases in mortalities were sudden in the third year after Day 19, whereas they were more gradual in the other cases (Figs. 1 \& 2). Expt 4 illustrates how lower larval densities result in lower mortality levels (Fig. 2). Early signs, including velar damage with necrosis and detachment of velar cells, were observed before settlement and death of larvae.

Prior to mortalities, larvae without antibiotic grew more slowly but not significantly so (Student's $t$-test, p > 95\%) (Table 1). 

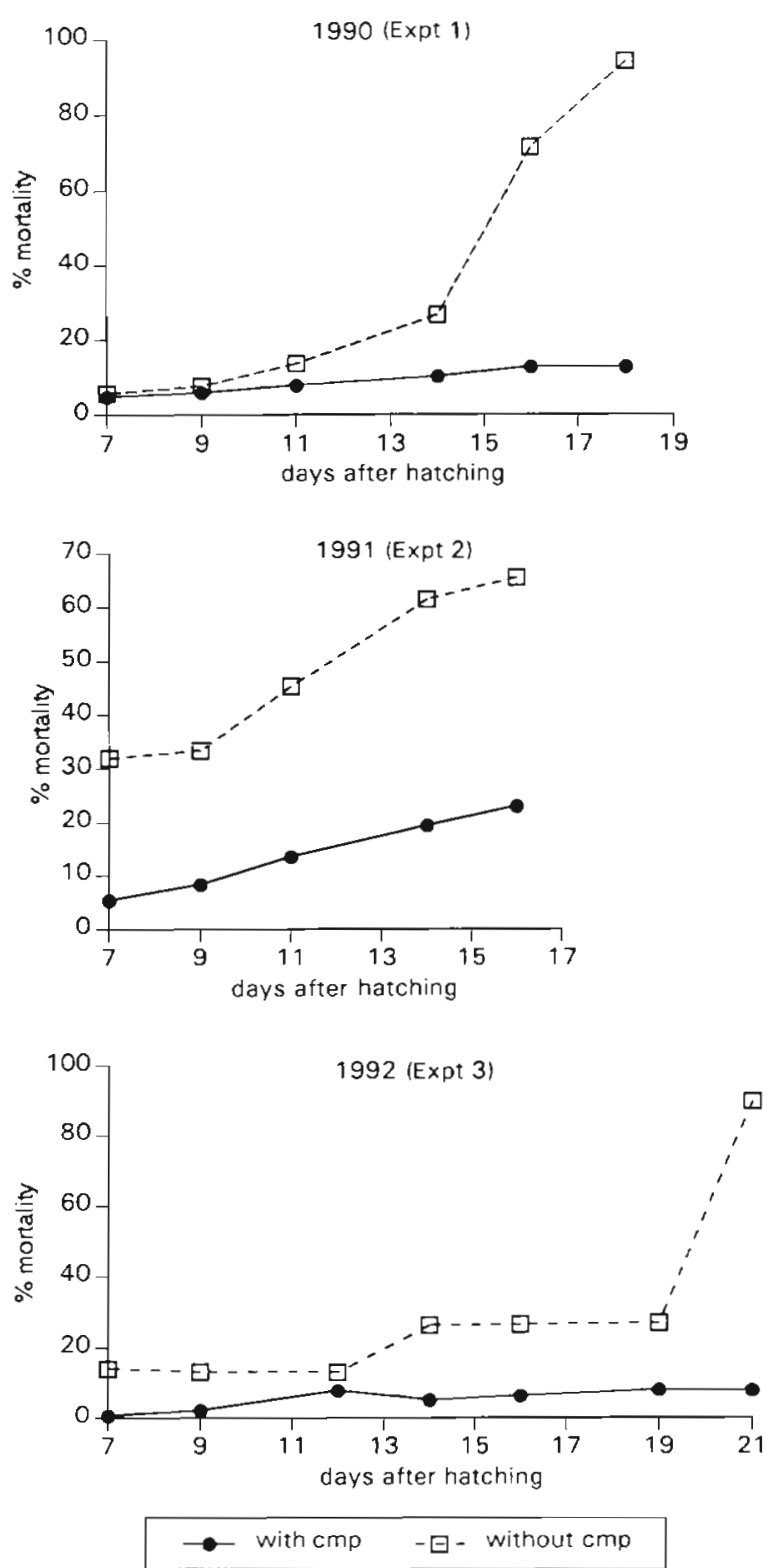

Fig. 1. Cumulative mortality of scallop larvae cultured with or without chloramphenicol $(\mathrm{cmp})$ for the 3 first rearings

\section{Development of bacterial populations}

In 1990 (Expt 1), vibrios counted on TCBS were more numerous in non-treated larvae than treated larvae (Fig. 3a). As soon as Day 7 , vibrios had progressively invaded non-treated larvae, but on the last day of the experiment TCBS revealed many fewer vibrios. This was probably due to an inhibiting factor of this agar, since half of the colonies collected on marine agar were fermentative and were identified later as species of vibrio. This problem was already encounted: some species of vibrios cannot grow on TCBS. In fact the

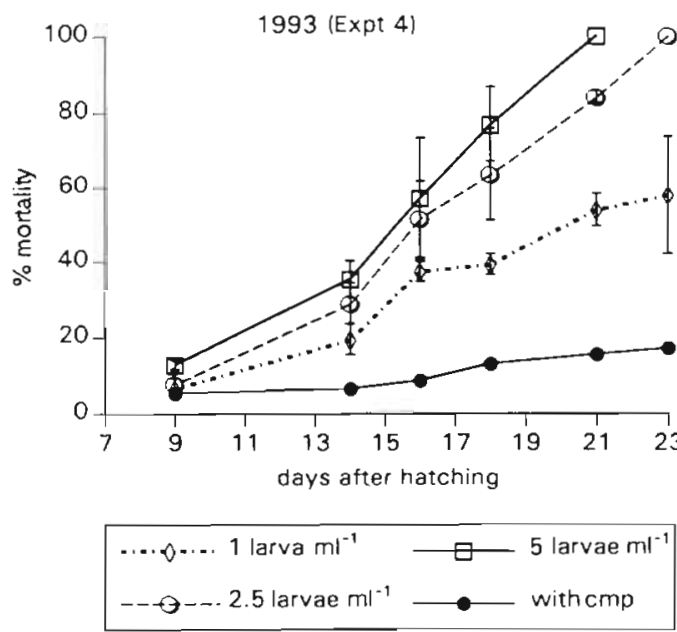

Fig. 2. Cumulative mortality of scallop larvae at different densities $\left(1,2.5\right.$ and 5 larvae $\left.\mathrm{ml}^{-1}\right)$ of larvae cultured without chloramphenicol (cmp) and at 5 larvae $\mathrm{ml}^{-1}$ with cmp (control)

Table 1. Daily growth rate in $\mu \mathrm{m} \mathrm{d}^{-1}$ (SD) before outbreak with or without chloramphenicol (cmp)

\begin{tabular}{|lcc|}
\hline & With cmp & Without cmp \\
\hline Expt 1 & $6.99(0.79)$ & $6.69(0.77)$ \\
Expt 2 & $5.08(0.66)$ & $4.35(0.50)$ \\
Expt 3 & $7.02(0.58)$ & $6.44(1.05)$ \\
\hline
\end{tabular}

absence of colonies on TCBS may reveal a change of vibrio populations in non-treated larvae.

In 1991 (Expt 2), vibrio numbers in both SW and nontreated larval cultures were 10 -fold to 100 -fold higher in cultures without antibiotic and vibrio densities increased dramatically after Day 11 (Fig. 3b).

In the non-treated batch in 1992 (Expt 3), vibrios had attained high concentrations by Day 5 in sea water but then decreased between Day 9 and Day 14. They again reached high levels at Day 16 before the onset of mortality (Fig. 3c).

In the fourth experiment, vibrios were also numerous in the 3 batches of larvae without antibiotic (Fig. 4a) On Day 14, vibrios achieved concentrations greater than $10^{2}$ cells $\mathrm{ml}^{-1}$ and remained at this concentration until mortality occurred. In the control batch neither vibrios nor total bacteria were checked, but vibrios probably followed the same trends as in the previous experiments.

In contrast to the vibrio populations, total bacterial densities were generally similar in the treated and in the non-treated larvae and SW over the experiment. In Expt 2, they varied between $10^{4}$ and $10^{5}$ cell $\mathrm{ml}^{-1}$ in SW for both conditions; in both batches of larvae the concentrations increased from $2.1 \times 10^{1}$ (Day 7 ) to 5 to $8 \times 10^{2}$ cell larva ${ }^{-1}$ (Day 16$)$. 
From Day 12, the bacterial density in Expt 3 (1992) was on average 10 -fold more numerous in the treated batch than in the untreated one. It increased

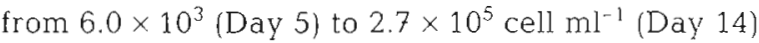
and stabilized around $10^{5}$ cell $\mathrm{ml}^{-1}\left(6.8 \times 10^{4}\right.$ to $2.4 \times$ $10^{5}$ ). Concentration of bacteria in larvae tended also to increase over the experiment and varied from 2.1 $\times 10^{1}$ to $2.5 \times 10^{3}$ cell larva $^{-1}$

In Expt 4 (Fig. 4b), concentrations of bacteria in SW of 3 untreated batches were very uniform and varied only between $4.7 \times 10^{4}$ and $2.3 \times 10^{5} \mathrm{cell} \mathrm{ml}^{-1}$, except for 1 sample at $9.0 \times 10^{3}$ cell $\mathrm{ml}^{-1}$.
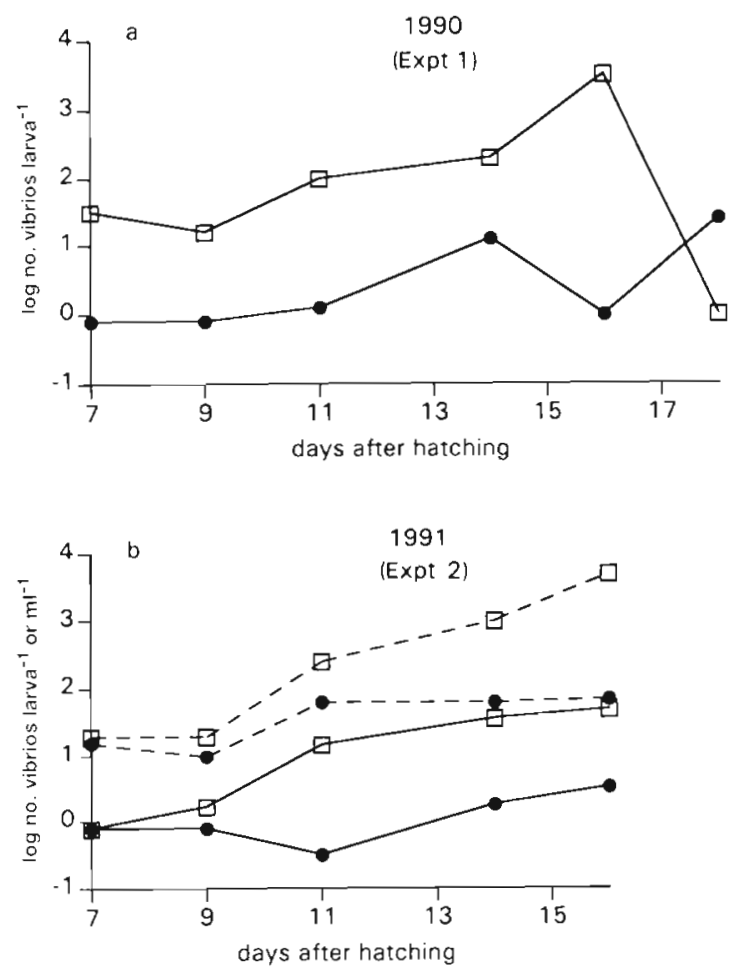
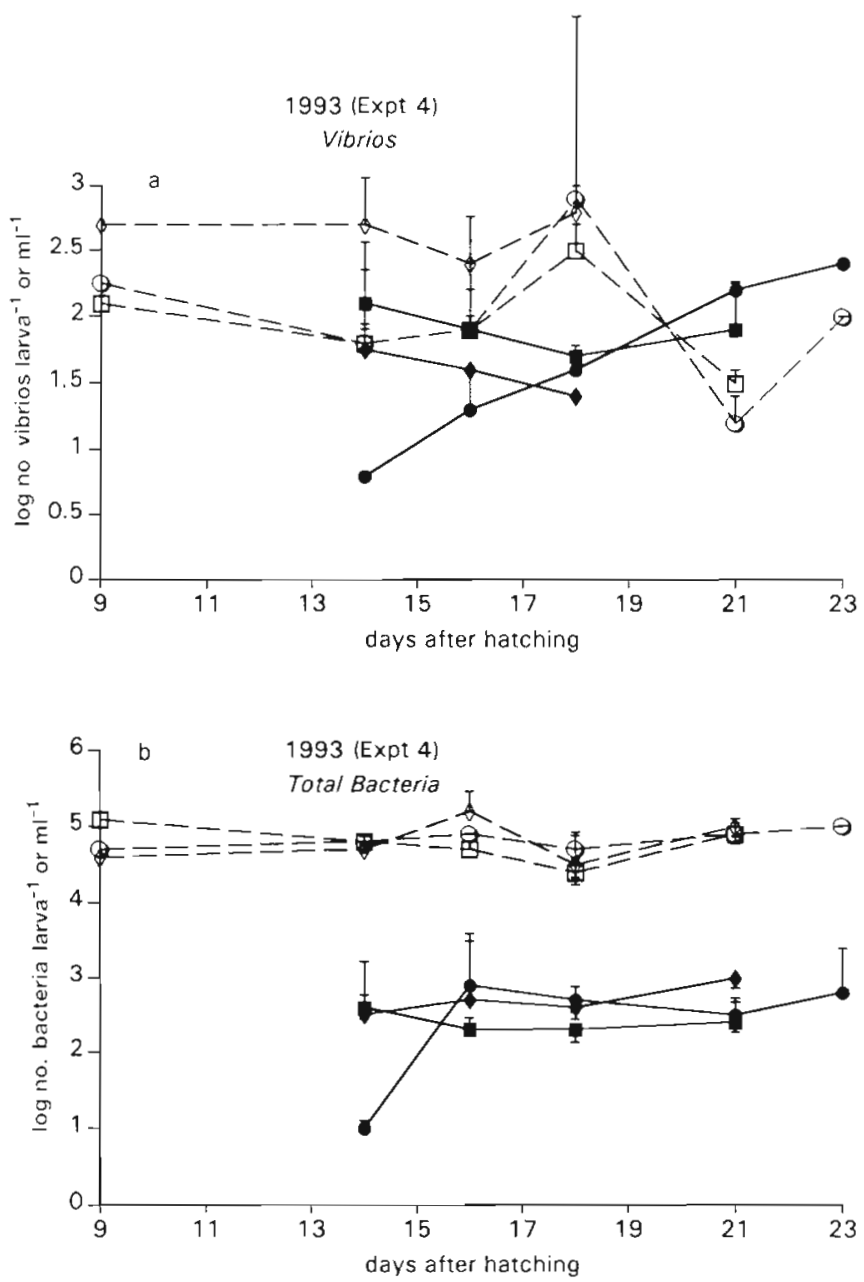

\begin{tabular}{|c|c|c|c|c|}
\hline$-\ominus-\begin{array}{l}\text { SW with } \\
1 \text { larva ml }\end{array}$ & $-\oplus-$ & $\begin{array}{l}\text { SW with } \\
5 \text { larvae } \mathrm{ml}^{-1}\end{array}$ & & $\begin{array}{l}\text { larval conc.: } \\
2.5 \text { larvae } \mathrm{ml}^{-1}\end{array}$ \\
\hline$\exists-\begin{array}{l}\text { SW with } \\
2.5 \text { larvae } \mathrm{ml}^{-1}\end{array}$ & & $\begin{array}{l}\text { larval conc.: } \\
1 \text { larva } \mathrm{ml}^{-1}\end{array}$ & & $\begin{array}{l}\text { larval conc: } \\
5 \text { larvae } \mathrm{ml}^{-1}\end{array}$ \\
\hline
\end{tabular}

Fig. 4. Change of (a) vibrio concentrations and (b) total bacterial flora in larvae and in sea water (SW), without the addition of chloramphenicol in the culture (1993)

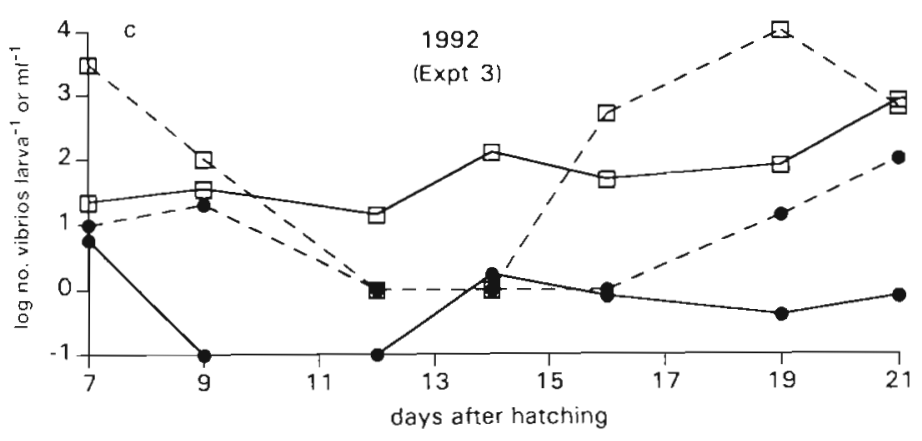

larvae +cmp $\square$ larvae - cmp

$\mathrm{SW}+\mathrm{cmp} \quad-\rightarrow \mathrm{SW}-\mathrm{cmp}$

Fig. 3. Change of vibrio concentrations in larvae and in sea water (SW), with or without addition of chloramphenicol $(+\mathrm{cmp},-\mathrm{cmp})$ in culture in (a) 1990, (b) 1991 and (c) 1992

\section{Identification and clustering of bacteria}

A total of 181 different colonies of the dominant bacterial flora from the 3 first experiments on both media (TCBS and Zobell) were purified and identified. Of these, 82 strains came from antibiotic-free culture, the others from treated culture.

All strains were Gram negative and rodshaped, and most of them required $\mathrm{NaCl}$ for growth.

Four clusters of vibrios were identified in antibiotic-free batches, whereas no such clustering occurred in the treated batches, except for the minor phenotype $\mathrm{F}$ (Fig. 5). Cluster C 


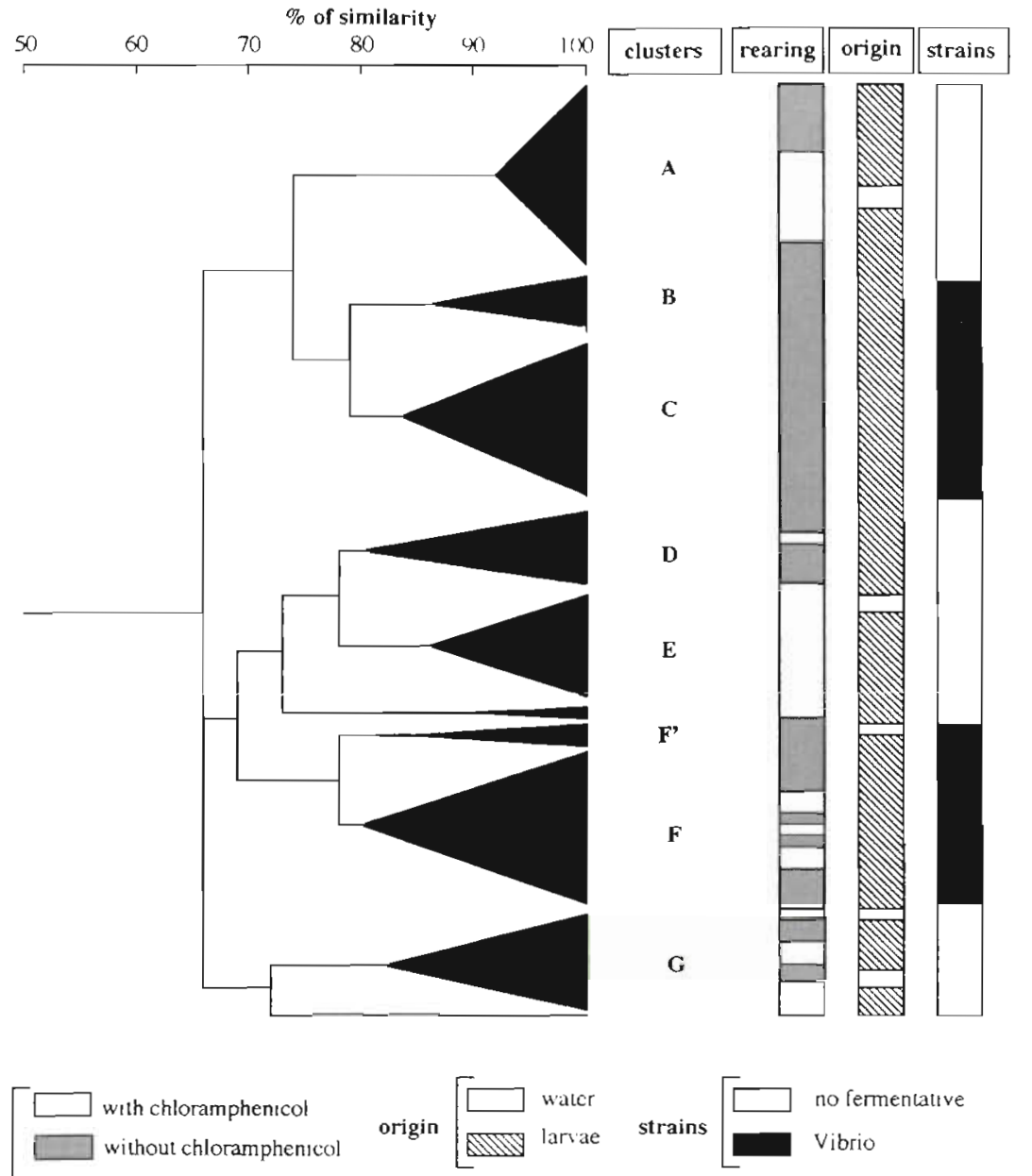

Fig. 5. Dendrogram of 181 bacterial strains, identified by 40 characters. isolated in larvae and sea water from 3 years (1990, 1991 and 1992). The clusters $B, C, F^{\prime}$ and $F$ included only fermentative strains was more regularly isolated on Zobell agar than on TCBS, where it grew poorly. In 1990, 4 groups of vibrios $\left(B, C, F, F^{\prime}\right)$ were present, whereas only 1 occurred in 1991 and both ( $\mathrm{F}$ and $\mathrm{F}^{\prime}$ ) were isolated in the third year. The isolates belonging to clusters $C$ and $F$ were dominant, whereas both $B$ and $C$ were minor with regard to concentration. It was possible to isolate these vibrio strains about $7 \mathrm{~d}$ before the onset of mortalities,

Table 2. Clustering of isolates according to different methods

\begin{tabular}{|c|c|c|c|c|}
\hline & Proteins & $\begin{array}{l}\text { Classical } \\
\text { characters }\end{array}$ & Biolog & $\begin{array}{c}\mathrm{GC} \\
\text { content. }\end{array}$ \\
\hline A 053 & \multirow{4}{*}{ Group A } & \multirow{4}{*}{ Group A } & \multirow{4}{*}{ Group A } & $48.8-48.9$ \\
\hline A 515 & & & & 48.9 \\
\hline V 110 & & & & 48.9 \\
\hline V. splendidus & & & & $48.1-48.9$ \\
\hline A 365 & \multirow{3}{*}{ Group B } & \multirow[t]{2}{*}{ Group B } & \multirow{3}{*}{ Group B } & 44.5 \\
\hline A 060 & & & & 44.7 \\
\hline V. alginolyticus & & & & 47.6 \\
\hline S 322 & \} Group C & Group C & Group C & 49.3 \\
\hline
\end{tabular}

after which time they became progressively dominant in sea water as well as in larvae. For the fourth experiment only cluster $C$ was isolated and represented by the strain A 601

Identification of representative isolates, including A 053, A 515 (cluster F) A 060, and A 365, confirmed the existence of 2 vibrio species (see Fig. 6 \& Table 2). Isolate V 110 from moribund oyster is very close to A 053 and A 515 identified by either method. In contrast, the reference strains of Vibrio splendidus and $V$. alginolyticus are taxonomically different depending upon the method used. However, the phylogenetic analysis of $16 \mathrm{~S}$ rRNA sequences (Fig. 7) of our isolates affiliates the groups A 053, A 515 and $V 110$ with $V$. splendidus in agreement with Biolog tests. The 2 other groups, including the groups A 060 . A 365, A 601 and the group S 322 and I 168 may represent 2 new species of vibrio. 

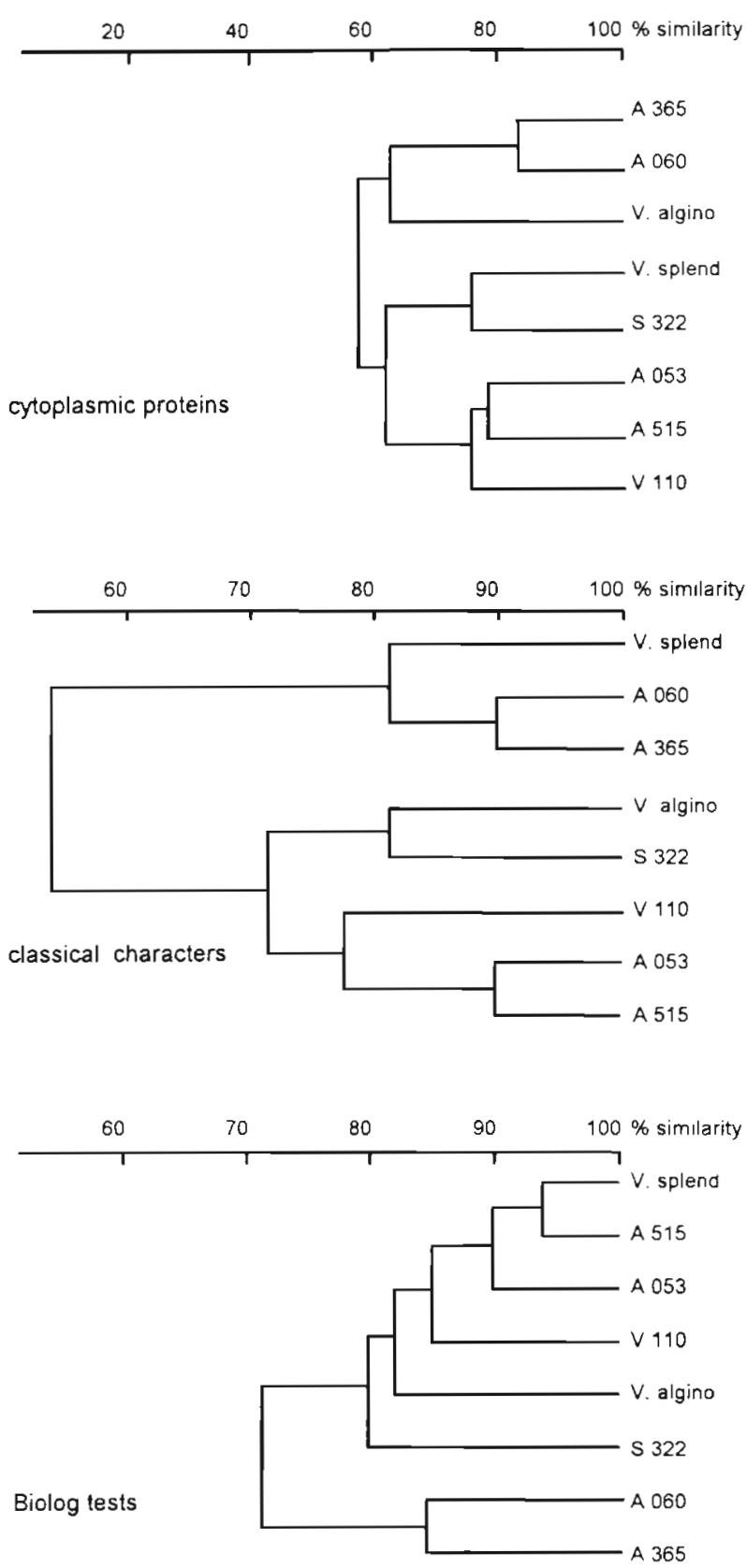

Fig. 6. Dendrograms deduced from different phenotypic methods of identification of isolated strains and reference species. V. algino: Vibrio alginolyticus; V. splend.. Vibrio splendidus

\section{Experimental exposures}

The strains A 053 and A 515, representing cluster F, and the strains A 365 and A 060, belonging to cluster $C$, caused mortalities of scallop larvae, whereas the vibrio T 416 was non-pathogenic. All pathogenic strains induced serious losses but only after $72 \mathrm{~h}$ exposure (Fig. 8).

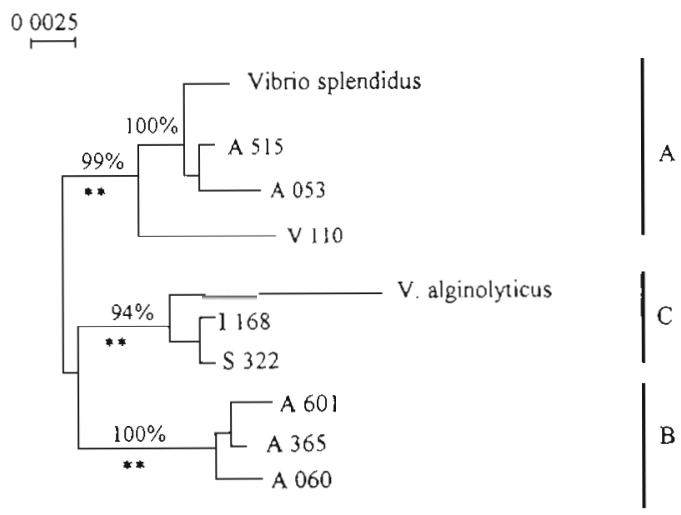

Fig. 7 Phylogenetic analysis of the pathogenic bacteria isolated in scallop and oyster larvae. The topology shown was obtained using the neighbour-joining method; branches significantly positive at $p>0.01$ using maximum likelihood are indicated by ${ }^{\prime}$; percentages corresponding to a bootstrap analysis using maximum parsimony are indicated above every branch for branches obtained in the most parsimonious tree

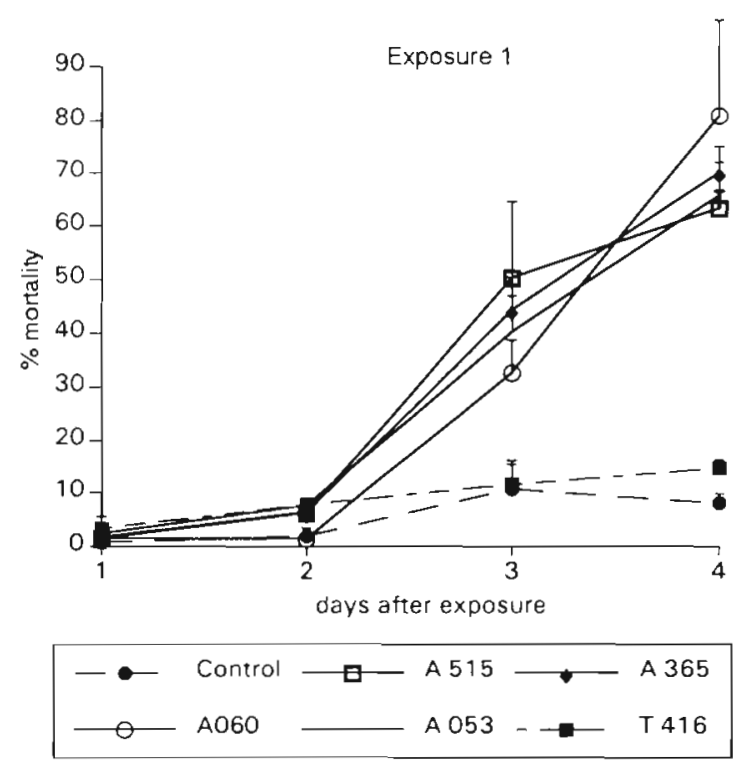

Fig. 8. Pecten maximus. Experimental exposure of scallop larvae to bacteria (A 515, A 053, A 365, A 060) representing the major clusters of fermentative strains and a non-fermentative isolate (T 416) from moribund scallop larvae

The virulent strains A 060, A 15, A 053 and A 365 were easily isolated as dominant bacteria in larvae and sea water, while the strain T 416 disappeared $2 \mathrm{~d}$ after exposure.

In scallop larvae, $3 \mathrm{~d}$ after exposure to the strains S 322, I 168, V 110 and A 365 notable mortalities occurred only with strain A 365 (Fig. 9). Serious losses promptly appeared $48 \mathrm{~h}$ after exposure and reached 
Exposure 2
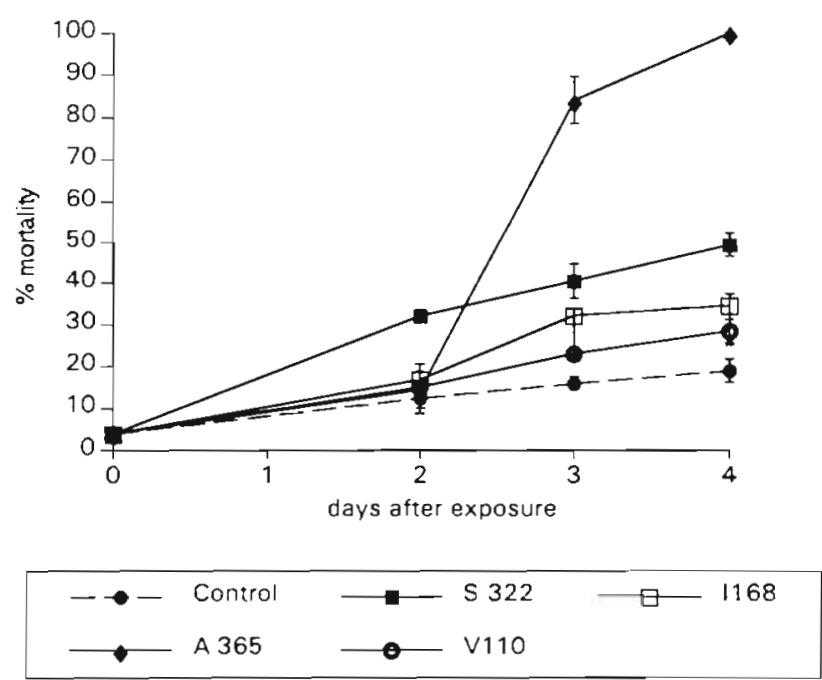

Fig. 9. Pecten maximus. Experimental exposure of scallop larvae to fermentative strains isolated in moribund oyster (Crassostrea gigas and Ostrea edulis) larvae (S 322, V 110 and I 168) and the strain A 365 from scallop larvae

almost $100 \%$ at Day 4 . With strain S $32230 \%$ mortality was observed as soon as $48 \mathrm{~h}$ after exposure but increased slowly after this. The other strains appeared almost innocuous (Fig. 9). Isolate A 365 was easily collected as a dominant species on Zobell agar. The other inoculated strains were lesser contributors to the microflora until the end of sampling.

In 2 further experimental exposures with scallop larvae, isolate A 365 exhibited the same virulence whereas isolate A 515 provoked only about $30 \%$ mortality in scallop larvae (Table 3 ).

Inoculation of oyster larvae (Crassostrea gigas) with A 365 did not provoke significant loss of larvae whereas the other strains, S 322, V 110 and I 168, induced mass mortality between Day 3 and Day 6 (Fig. 10). All strains were isolated again in dominant flora at Day 4

\section{DISCUSSION}

This study permitted an examination of the cause of outbreaks of disease that occur in scallop larvae cultured without antibiotic. Two clusters of bacterial strains isolated only from diseased scallop larvae caused mortalities in experimental infections, whereas other vibrios were innocuous to scallop larvae.

The 4 strains tested did not appear to be very virulent since collapse only occurred after a delay of 2 to $4 \mathrm{~d}$ depending on the experimental infection and after about 2 wk at the hatchery. However, this delay could be due to the type of infection in question or to larval sensitivity that could change depending upon the
Table 3. Comparison of virulence of strains A 365 and A 515 over 3 experiments. Mortality in percent (SD) of scallop larvae 5 and 6 d after exposure

\begin{tabular}{|cccccc|} 
& \multicolumn{2}{c}{ A 365 } & \multicolumn{2}{c|}{ A 515 } \\
& Day 4 & Day 6 & & Day 4 & Day 6 \\
\hline Expt 1 & $70.0(2.0)$ & $100(0)$ & & $63.3(3.2)$ & $100(0)$ \\
Expt 2 & $45.5(7.8)$ & $100(0)$ & $36.2(9.8)$ & $38(11.3)$ \\
Expt 3 & $100(0)$ & & 32 & $(2.8)$ & $33(4.2)$ \\
\hline
\end{tabular}

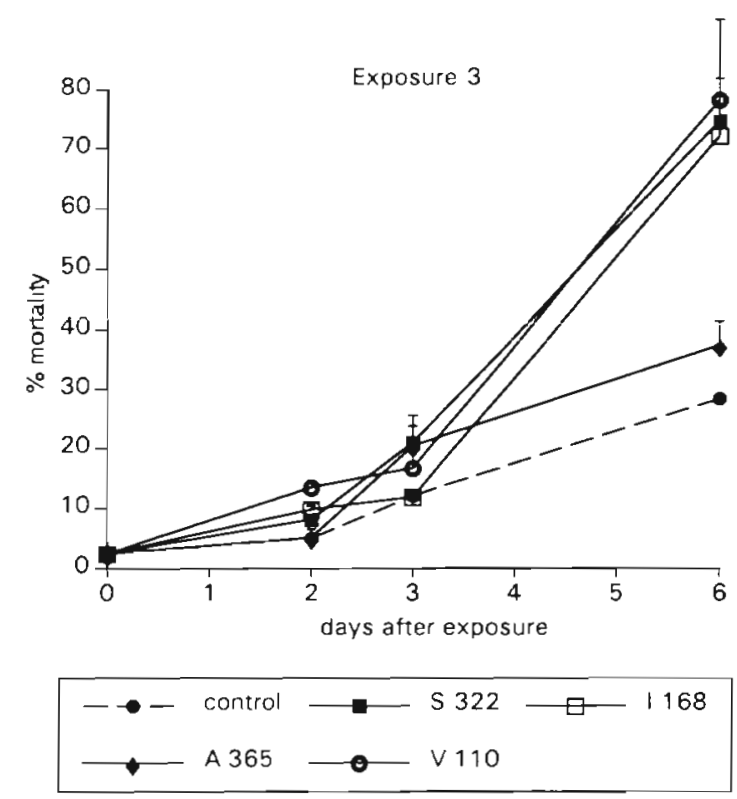

Fig. 10. Crassostrea gigas. Experimental exposure of oyster larvae to the fermentative strains isolated in moribund oyster larvae and the strain A 365 from scallop larvae

source of the larvae rather than to a lack of virulence. Cluster $F$ is similar to Vibrio splendidus based on the characters determined by Biolog GN plates. This was confirmed by the phylogenetic analysis deduced from their 16S rRNA sequences (Fig. 6). For the second cluster (C), further tests will be needed before a new species can be proposed. This cluster must be considered the main pathogen of scallop larvae since it was repeatedly isolated. The other $(F)$ is probably more an opportunist rather than a true pathogen.

A similar study was conducted by Jeffries (1982) with oyster (Crassostrea gigas) larvae. She isolated 3 vibrios in moribund larvae that were able to attack oyster larvae in experimental infection. These isolates plus 3 other previously isolated from diseased bivalve larvae and provided by Milford, Connecticut, USA, were close to Vibrio splendidus and $V$. anguillarum Biovar 2 on the basis of their phenotypic characters. Except for this report $V$. splendidus has not previously been described as a pathogen. 
However, many pathogens collected in moribund larvae (DiSalvo et al. 1978, Elston \& Leibovitz 1980, Brown 1981) are affiliated with species which have only some phenotypic characters or are not affiliated at. all. Consequently, the taxonomic position of isolates is often uncertain, thus preventing a real comparison and communication between laboratories. Fortunately, in the near future, phylogenetic analysis deduced from the sequences of $16 \mathrm{~S}$ rRNA will provide a clearer taxonomic position of new isolates (Ruimy et al. 1994). Most isolates appeared to be very specific since they attacked either scallop larvae or oyster larvae but not both bivalve species. However, strain S 322 exhibited a moderate detrimental effect on scallop larvae. This specificity of virulent bacteria has not previously been reported, except for the pathogenic bacteria named VTP, isolated in moribund Manila clam larvae (Nicolas et al. 1992).

Specificity could be due to different virulence factors, such as attachment, as previously suggested for VTP and observed by Elston \& Leibovitz (1980). Their specificity may be also a function of the toxins that they produce. Thus, E. Lane \& T. H. Birkbeck (pers. comm.) showed that haemocytes rapidly became rounded when they were exposed to virulent bacteria. The rounding response was more rapid when the haemocytes of scallop (Pecten maximus) were exposed to strain A 365 than when exposed to other pathogenic vibrios. Conversely, the haemocytes from other bivalves (oysters, clams, mussel) showed a weaker response when they were incubated with strain $\mathrm{A} 365$.

A comparison of phenotypic characters and 16.5 rRNA sequences showed that strain A 515 seems to be identical to a virulent strain regularly isolated in diseased turbot larvae (Gatesoupe 1991). Cross-experimental infection with scallop and turbot larvae will be necessary to assess the identity of both strains.

Finally, it appears that pathogenic bacteria of bivalve larvae are more ubiquitous than previously thought or, conversely, more specific than previously supposed.

The mechanism of infection was not investigated in this study. However, both pathogens may be invasive since they started to colonise larvae at least $1 \mathrm{wk}$ before outbreak. In addition, strain A 365 has been shown to produce toxins, especially thermostable toxins. The crude supernatant of $72 \mathrm{~h}$ old bacterial culture as well as that heated to $100^{\circ} \mathrm{C}$ killed axenic oyster larvae (Nicolas et al. unpubl.). This toxin may be equivalent to the ciliostatic toxin reported by Nottage et al. (1989) and widespread in vibrios. A 365 may also possess endotoxins. Indeed, rapid settlement of larvae was observed when axenic oyster larvae were inoculated with bacterial cells of this isolate, broken by sonication and filtered at $0.2 \mu \mathrm{m}$. The ability of strain A 365 to cause rounding of scallop haemocytes faster than other virulent bacteria may be related to the presence of endotoxins since bacteria affect haemocytes after phagocytosis

High concentrations of vibrios $\left(10^{4}\right.$ cell $\mathrm{ml}^{-1}$ on TCBS) in sea water, observed before collapse, could produce significant amount of toxins. However, progressive mortality can hardly be explained by the effect of toxins released in sea water Toxins may simultaneously affect all larvae and not just a small part of the larval population. In the third year (1992) collapse of larvae was sudden and was related to a high level of vibrio A 515 in the sea water. In this particular case, toxins in the sea water may be considered to have been a possible cause of collapse.

The mechanism of infection may be a combination of invasive and toxic pathways. Over certain concentration levels in the gut, vibrios lysed by digestive enzymes could release large amount of toxins (ciliostatic toxin, proteases, endotoxins) which would stop the digestive transit and start to degrade tissues. Subsequent growth of vibrios would strengthen this attack until all tissues have been invaded. This route of infection conforms to that of type III pathogenesis reported by Elston \& Leibovitz (1980)

For prevention of diseased scallop larvae, an alternative method to the use of antibiotics must be developed. Pathogens have certainly been carried by inlet sea water and/or in scallop breeders. Larval cultures could be protected from contamination by means of UV treatment of the inflowing sea water and by antibiotic treatment of the scallop eggs.

Acknowledgements. This study was supported by the European Community, DG XIV (Program FAR 1, Contract No. AQ $1263)$.

\section{LITERATURE CITED}

Baumann P, Baumann L (1981) The marine Gram negative eubacteria. In: Starr MP, Stolp H. Trüper HG, Balows A, Shlegel (eds) The Prokaryotes, a handbook on habitats, isolation and identification of bacteria. Springer-Verlag, Berlin, p 518-538

Brown C (1981) A study of two shellfish-pathogenic Vibrio strains isolated from a long island hatchery during a recent outbreak of disease. J Shellfish Res 1:83-87

Brown C, Russo DJ (1979) Ultraviolet light disinfection of shellfish hatchery sea water. 1. Elimination of five pathogenic bacteria. Aquaculture 17:17-23

Brown C. Tettelbach LP (1988) Charcaterization of a nonmotile Vibrio sp. pathogenic to larvae Mercenaria mercenaria and Crassostrea virginica. Aquaculture 74:195-204

De Ley J (1970) Re-examination of the association between melting point, buoyant density and chemical base composition of deoxyribonucleic acid. J Bacteriol 101:738-754

Devauchelle N, Mingant C (1991) Review of the reproductive physiology of the scallop Pecten maximus, applicable to intensive aquaculture. Aquat Living Resour 4:41-51 
DiSalvo LH, Bleka J, Zebal R (1978) Vibrio anguillarum and larval mortality in a California coastal shellfish hatchery. Appl Environ Microbiol 35:219-221

Elston RA, Leibovitz I (1980) Pathogenesis of experimental vibriosis in larval American oysters, Crassostrea virginica. Can J Fish Aquat Sci 37:964-978

Elston RA (1984) Prevention and management of infectious diseases in intensive mollusc husbandry. J World Mlaricult Soc 15:284-300

Gatesoupe FJ (1991) Experimental infection of turbot, Scophthalmus maximus (L.), larvae with a strain of Aeromonas hydrophila. J Fish Dis 14:495-498

Gruffydd LD. Beaumont AR (1970) Determination of the optimum concentrations of eggs and spermatozoa for the production of normal larvae in Pecten maximus. Helgol Wiss Meeresunters 20:486-497

Jackman PJ (1985) Bacterial taxonomy based on electrophoretic whole-cell protein patterns. In: Goodfellow M. Minnikin DE (eds) Chemical methods in bacterial systematics. Academic Press, London, p 115-129

Jeffries VE (1982) Three Vibrio strains pathogenic to larvae of Crassostrea gigas and Ostrea edulis. Aquaculture 29: 201-226

Lowry OH, Rosebrough NJ, Farr AL, Randall RJ (1951) Pro-

Responsible Subject Editor: A. K. Sparks, Seattle, Washington, USA tein measurement with Folin phenol reagent. J Biol Chem 193:265-275

MacDonell MT, Singleton FL, Hood MA (1982) Diluent composition for use of API 20E in characterizing marine and estuarine bacteria. Appl Environ Microbiol 44:423-427

Martin Y, Vicente N (1975) Action des antibiotiques sur les cultures de larves de mollusques bivalves. Essai sur Mytilus galloprovincialis (Lmk). Rev Int Océanogr Méd 39-40:53-69

Nicolas JL, Ansquer D, Cochard JC (1992) Isolation and characterisation of pathogenic bacterium specific to Manila clam, Tapes philippinarum, larvae. Dis Aquat Org 14: 153-159

Nottage AS, Sinclair PD, Birkbeck TH (1989) Role of lowmolecular-weight ciliostatic toxins in vibriosis of bivalve mollusks. J Aquat Anim Health 1:180-186

Ruimy $R$, Breittmayer $V$, Elbaze $P$, Lafay $B$, Boussemart $O$. Gauthier M, Richard C (1994) Phylogenetic analysis and assessment of the genera Vibrio, Photobacterium, Aeromonas and Plesiomonas deduced from small-subunit rRNA sequences. Int J Syst Bacteriol. 44:416-426

Standiford HC (1985) Tetracyclines and chloramphenicol. In: Mandell GL, Douglas RG, Bennett JE (eds) Anti-infective therapy. John Wiley and Sons, New York, p 147-174

Manuscript first received: February 27, 1995

Revised version accepted: February 22, 1996 